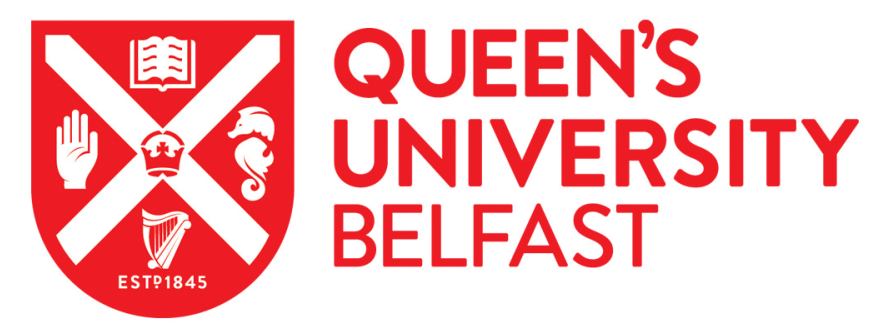

\title{
The Balliol That Might Have Been: Pugin's Crushing Oxford Defeat
}

Litvack, L. (1986). The Balliol That Might Have Been: Pugin's Crushing Oxford Defeat. Journal of the Society of Architectural Historians, 45(4), 358-373. https://doi.org/10.2307/990207

Published in:

Journal of the Society of Architectural Historians

Document Version:

Publisher's PDF, also known as Version of record

Queen's University Belfast - Research Portal:

Link to publication record in Queen's University Belfast Research Portal

\section{General rights}

Copyright for the publications made accessible via the Queen's University Belfast Research Portal is retained by the author(s) and / or other copyright owners and it is a condition of accessing these publications that users recognise and abide by the legal requirements associated with these rights.

Take down policy

The Research Portal is Queen's institutional repository that provides access to Queen's research output. Every effort has been made to ensure that content in the Research Portal does not infringe any person's rights, or applicable UK laws. If you discover content in the Research Portal that you believe breaches copyright or violates any law, please contact openaccess@qub.ac.uk. 
SOCIETY OF

ARCHITECTURAL

HISTORIANS

The Balliol That Might Have Been: Pugin's Crushing Oxford Defeat

Author(s): Leon B. Litvack

Source: Journal of the Society of Architectural Historians, Vol. 45, No. 4 (Dec., 1986), pp. 358-373

Published by: University of California Press on behalf of the Society of Architectural Historians

Stable URL: http://www.jstor.org/stable/990207

Accessed: 21-12-2017 15:53 UTC

JSTOR is a not-for-profit service that helps scholars, researchers, and students discover, use, and build upon a wide range of content in a trusted digital archive. We use information technology and tools to increase productivity and facilitate new forms of scholarship. For more information about JSTOR, please contact support@jstor.org.

Your use of the JSTOR archive indicates your acceptance of the Terms \& Conditions of Use, available at http://about.jstor.org/terms

Society of Architectural Historians, University of California Press are collaborating with JSTOR to digitize, preserve and extend access to Journal of the Society of Architectural Historians 


\title{
The Balliol that Might Have Been: Pugin's Crushing Oxford Defeat
}

\author{
LEON B. LITVACK University of Edinburgh
}

\begin{abstract}
Augustus Welby Pugin (Fig. 1) was the acknowledged leader of the Gothic revival in 19th-century England. Examples of his work appear everywhere in the country-everywhere, that is, except $O x$ ford. This man was guided by strict principles of "pointed" or "Christian" architecture; however, unlike many architects of his day, Pugin's beliefs were also governed by a fervent -and sometimes oppressive-devotion to the Roman Catholic Church. He was convinced that outward signs of devotion were indispensable, and that the Church of Rome was the true expounder of Christian faith. Pugin would have loved to erect a building based on these principles in what he called "the most Catholic-looking city in England." The aim of this article is to demonstrate that the rejection of Pugin as architect for the new buildings at Balliol in 1843 was not simply a case of a Roman Catholic's working in a hostile Protestant environment; rather, he was dismissed because of the vehemence with which he pressed his own cause and derided that of others. Balliol was a great loss to Pugin; the course of events described in these pages serves as a painful reminder of overabundant zeal in pursuit of a goal.
\end{abstract}

AUGUSTUS WELBY PUGIN'S project for redesigning Balliol College in Oxford has always been surrounded with mystery. His work on this College could have been monumental: it would have been a fitting testimonial, in the center of one of the bastions of the Anglican Church, to the 19th-century Gothic revivalist, who firmly believed that "everything glorious about the English churches is Catholic, everything debased and hideous, Protestant." 1
In order to understand why the Balliol project ended in failure it is necessary to examine Pugin's sentiments on the Gothicity of Oxford, and also the history of his associations with the city up to the time of the Balliol episode in 1843. Ever since the founding of the Oxford Movement in 1833, the city had become a great center of activity for Protestants interested in a restoration of some of the doctrines and practices of the original English Church. This revival had great implications for English Roman Catholics, and it was in their best interests to follow closely the efforts of their Anglican countrymen. The movement was led by John Henry Newman, and included among its aims the forwarding of the idea that the Church of England was not founded at the Reformation but was the historic Catholic Church of the land. It is understandable that Pugin, who was so concerned with Church reunion and with the ancient-and Roman Catholicroots of the English Church, would have viewed the course of events in Oxford as a harbinger of the eventual union of the Churches. He believed that Gothic, which was the style of the medieval English churches, was the only style appropriate for places of Christian worship in any era; the architect would therefore have wanted to contribute to a revival of both Gothic and Roman sentiments in what he called "the city of spires."2 Pugin outlined his feelings about Oxford in a letter to his friend Osmond:

It is impossible for me to give you an adequate idea of the interest of the city of Oxford, where at every turning you meet a buttress and face an oriel window. With what pleasure could I walk through the place with you, and point out the various places of interest it contains! ${ }^{3}$

1. A.W.N. Pugin, Contrasts, or a Parallel Between the Architecture of the 15th \& 19th Centuries, Shewing the Present Decay of Taste, Salisbury, 1836, 51 .

2. Oxford, Magdalen College Archives, MS. 528, letter no. 8 (1840); from Pugin to John Rouse Bloxam.

3. B. Ferrey, Recollections of A.W.N. Pugin and his Father Augustus Pugin, London, 1861, 87. Pugin had familiarized himself with Oxford while there on a sketching tour in the summer of 1833 . 


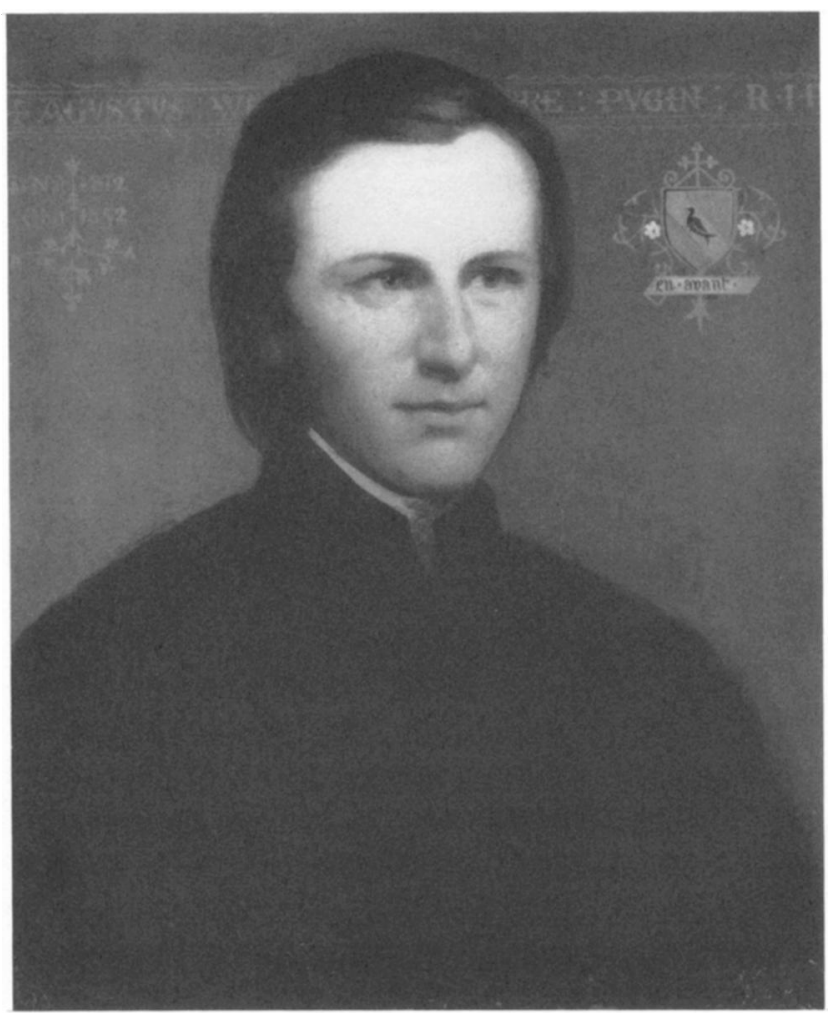

Fig. 1. Anonymous, portrait of Augustus Welby Pugin, c. 1840 (National Portrait Gallery, London).

To admire the Gothicity of Oxford was harmless enough; but for this Roman Catholic to attempt a revival of Christian architecture within the stronghold of the Anglican Church was quite a different matter: almost all of his valiant efforts were doomed to failure. The fact that Pugin belonged to the Church of Rome was certainly a contributory factor to his lack of success in Oxford, but not the predominant one: the following pages recount certain early actions taken by Puginyears before he contemplated any commissions in Oxfordwhich incited her inhabitants against him and cost him a very important commission. Although the failures he experienced did not detract significantly from his fame as an architect, these incidents troubled Pugin and served as reminders of the oppressive zeal with which he pursued the revival of Gothic/ Roman Catholic feeling in the England of his time.

Pugin had hoped that the Gothic revival would have a missionary effect and bring into the fold of the Roman Catholic Church Protestants for conversion as well as wandering Catholics who had allowed their religion to lapse. In a letter to

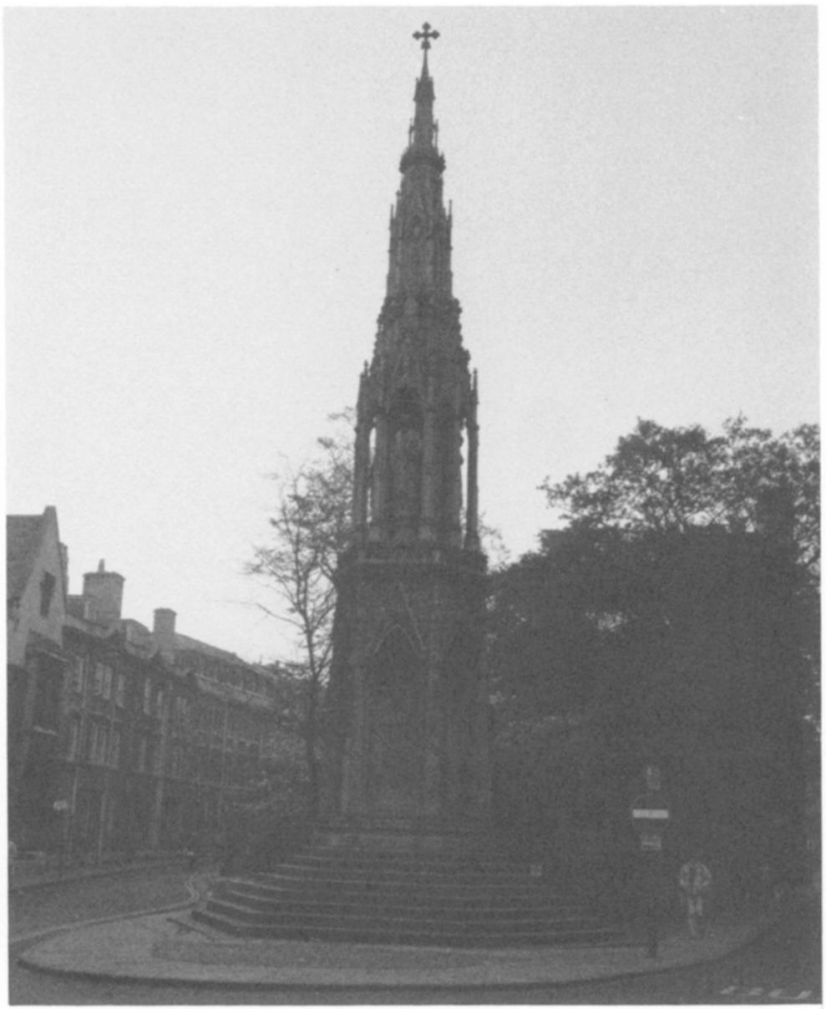

Fig. 2. Sir George Gilbert Scott, the Martyrs' Memorial, Oxford, 1841 (author).

his friend J. R. Bloxam in 1840 Pugin wrote: "You have no idea how all the English Catholics look to Oxford at the present time." 4 Pugin displayed great zeal for a Gothic revival; but his efforts were not tempered with discretion. His method of presenting his own position, and deriding that of others, proved to be the cause of his undoing. Such outspoken criticism is nowhere more evident than in his pamphlet of 1839 , entitled A Letter on the Proposed Protestant Memorial to Cranmer, Ridley, and Latymer, addressed to the Subscribers and Promoters of that Undertaking.

This publication was directed against the Martyrs' Memorial, which was built in the Gothic style by George Gilbert Scott in the Broad Street in 1841-1843 (Figs. 2-4). The project was devised by a low-church group to commemorate the Protestant bishops burned at the stake in 1555-1556. Pugin was vehemently opposed to the idea of a monument to these men-whom he in no way considered martyrs-as well as to its being built in the style through which he was trying to evoke the Catholic faith.

4. Oxford, Magdalen College Archives, MS. 528, letter no. 9; from Ramsgate, 11th day in Advent (9 December), 1840. Pugin rarely dated his letters; when he did it was usually in terms of events in the religious calendar. 


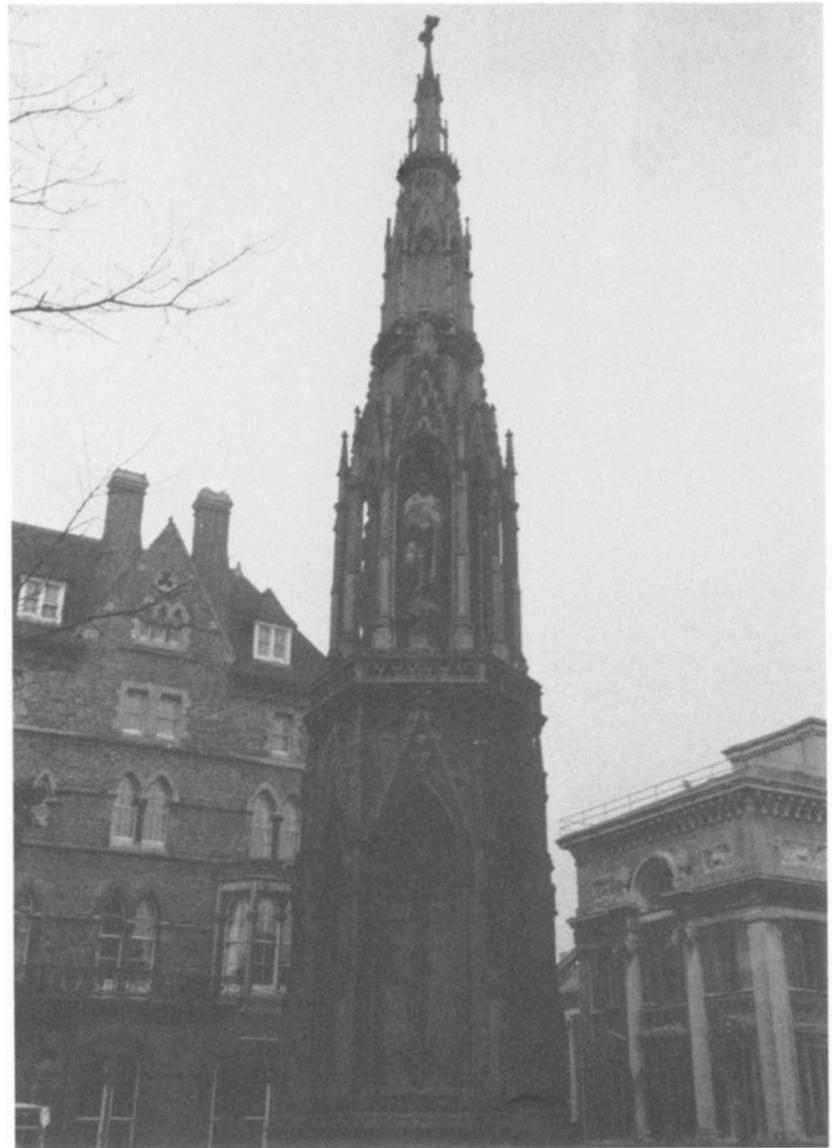

Fig. 3. Sir George Gilbert Scott, the Martyrs' Memorial, Oxford, 1841 (author).

Pugin's publication incensed the Conservative dons of Oxford, who were all Anglican clergy. The ferocity of the onslaught can be seen in the sharp, opening condemnation:

So gross, indeed, are the perversions of fact, that in charity I must suppose you either utterly ignorant of the history of your establishment, as set forth by your own historians, or, that you have so long tried to delude others in these matters, that you have at length deceived yourselves. . . . I am rather disposed to attribute the proposal of this monument to your ignorance; otherwise common prudence would have induced you to conceal as much as possible the disgraceful origin of your legal Establishment, instead of reviving the memory of its founders, whose conduct exhibits an almost unrivalled compound of dissimulation, cruelty, and weakness. ${ }^{5}$

These opening remarks were then supported by examples of questionable conduct from the lives of these martyrs. First, he accused Cranmer: "When, being a priest, and fellow of Jesus College, he privately kept a woman at the Dolphin Inn, Cambridge, and afterwards, while the Archbishop of Canterbury,

5. A.W.N. Pugin, A Letter on the Proposed Protestant Memorial to Cranmer, Ridley, and Latymer; Addressed to the Subscribers to and Promoters of that Undertaking, London, 1839, 3-4.

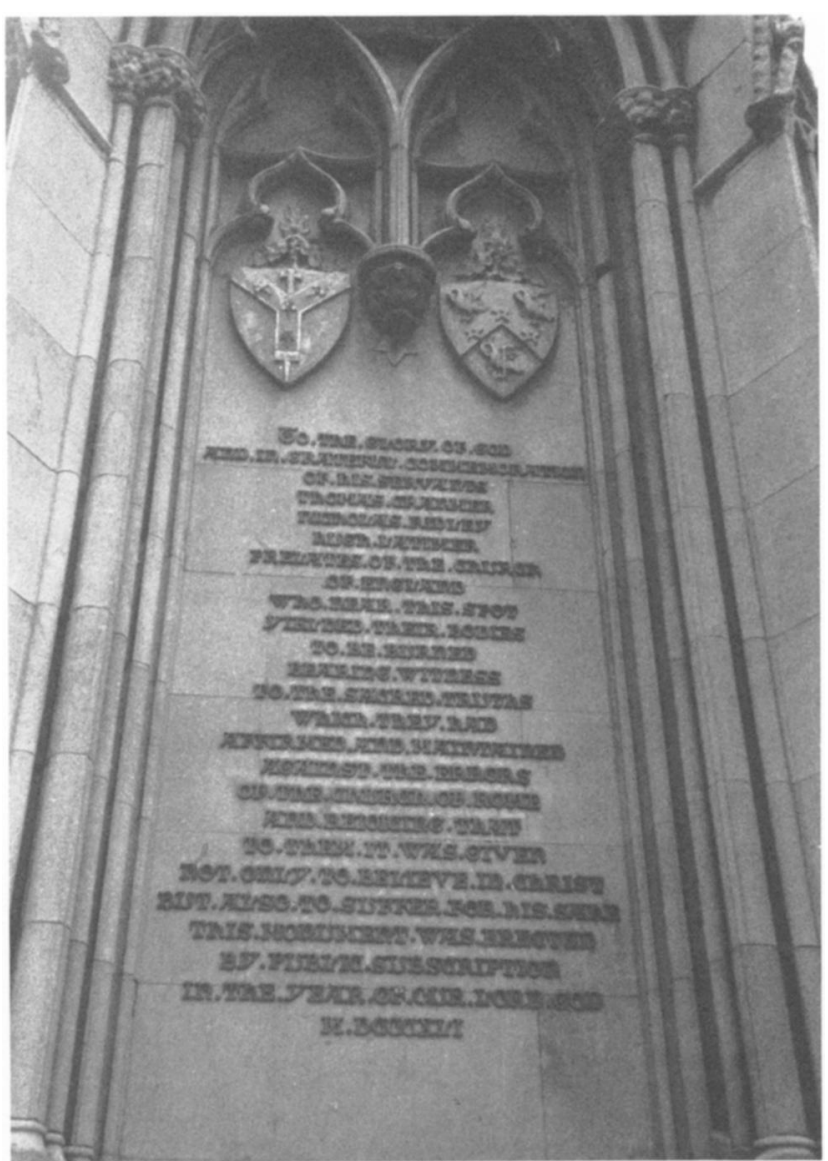

Fig. 4. Sir George Gilbert Scott, the Martyrs' Memorial, Oxford, 1841. Close-up of the inscription (author).

conveyed another about in a chest from his different palaces"; yet, "he daily said mass, vowed celibacy, submission, and obedience to the Pope." 6

Next, he attacked Latymer: "Like Cranmer, this pretended martyr, so far from exhibiting anything like firmness of faith or consistency, repeatedly abjured his opinions whenever he found himself endangered by them." 7 Pugin then cited four instances of Latymer's inconstancy from John Foxe's Acts and Monuments in order to substantiate his claim.

His third condemnation was of Ridley, who

appears to have imitated closely the conduct of Cranmer throughout his career. Like him, he was a violent persecutor of all persons holding Protestant opinions, during the reign of Henry. On the accession of Edward the Sixth, he joined in forwarding all the innovations; and while Cranmer was impoverishing the see of Canterbury, by alienating its lands, to propitiate the Duke of Somerset, Ridley consented to give up . . f four of the best manors belonging to the see of London, to gratify the courtiers of the day, conditional to his preferment to the bishoprick. ${ }^{8}$

6. Ibid., 4,5 .

7. Ibid., 18.

8. Ibid., 19. 
Pugin concluded that these men were highly unsuitable objects of a memorial. Even two years later, in a letter to Bloxam, he criticized the reverence felt for these martyrs by Protestants: "Surely no constant churchman can hold the name of Cranmer dear? . . Popular notions of history are so difficult to eradicate." 9

The Gothic revivalist's most scathing comments came toward the end of the pamphlet, where he chastised the Protestants for the tyranny which they had imposed upon the Roman Catholic Church and contrasted the present, degraded Anglican Church with the venerable Church of Rome:

The truth is, the legal establishment called the Church of England, with the Common Prayer, was first forced on this Catholic country by racks, noisome prisons, ripping up alive, clipping ears, boring tongues, fines, confiscations, harassing by pursuivants, tearing children from their parents, and tortures innumerable; and it has been afterwards maintained by enslaving the minds of people. Never has a nation been so deluded and hoodwinked as the English for the last two centuries; every source of historical information has been poisoned and perverted; and they have been successfully turned from examining your cruelties, by having those perpetuated by others continually magnified before your eyes. You have expatiated on the tyranny of Rome and the Catholic Church, that you might fetter them with vexatious laws and restrictions, drain their pockets, and fatten on their credulity; and now, at this time, do you trick them into payment of rates and all sorts of extortions, by keeping them in dread of popish faggots and inquisitions. . . The real cause of all this clamour is, that the whole fabric of your establishment exists on misrepresentation, and you dread all that approximates to truth, or exhibits facts in their true light. This Cranmer memorial is only a party scheme, another deception. . . . I confess I am roused to indignation when I find you venture to carry deception into the ancient city of Oxford, which owes its very existence to Catholic piety. But go on, erect your puny memorial, and when it is done it will cut but a sorry appearance among the venerable remains of ancient days that will surround it. ${ }^{10}$

The above passage seems to be the most polemical and volatile, and would therefore incite the Oxford authorities not only against the outspoken architect but also against Englisł Catholics in general. What made matters worse was that these comments on the proposed Martyrs' Memorial were not simply the passionate outpourings of an incensed Roman Catholic; rather, they were based on solid research. Given the turbulent atmosphere of the times, the pamphlet was well argued and historically correct, which was all the more reason for it to arouse animosity. It seems that in the opinion of the Oxford authorities Pugin was not only a man who said too much and said it too violently: he was a man who knew a little too much as well. Given the vehemence with which the architect mounted this attack on the Established Church, and the fact

9. Oxford, Magdalen College Archives, MS. 528, letter no. 13; from Ramsgate, St. Martin's Day (11 November), 1841. The tone is more measured in this letter to Bloxam than in the pamphlet. that the Master of Balliol College was a supporter of the Memorial, it is not surprising that his attempts to further a Gothic revival in Oxford ended in failure.

Before proceeding to describe the Balliol that never was, a few words must be said about the College's relations with an earlier architect, George Basevi. In 1841, while this man was engaged in replacing the roof of the Balliol chapel, he was asked to assess the state of all the College buildings, and to make recommendations for their improvement. He suggested rebuilding the façade from Trinity to the Fisher building at the corner of the Broad. He further suggested that the Master's Lodgings be removed to a new site at the lower end of the grove, in order to provide additional space for the College.

After his initial inspection of February 1842, Basevi visited Balliol a number of times, constantly reshaping his plans after discussions with his prospective employers. Unfortunately for him, there was no formal agreement between him and the College stating that he was to be the architect of the new buildings; he assumed from the proceedings that such was the case and was not led to believe otherwise.

Basevi had many obstacles to overcome in his desire to carry out the renovations. The individuals whom he in fact had to please were the Fellows and the Master of Balliol. The two Senior Fellows, Frederick Oakley and William George Ward, both prominent figures in the Oxford Movement, carried considerable weight at College meetings; however, in spite of their potential influence, they played a relatively small part in the controversy when compared to Balliol's Master, Dr. Richard Jenkyns.

Basevi had taken great pains to please the College officials, yet they were not satisfied: the architect's plans did not strive to maintain the Gothic harmony of the College buildings and were therefore declared unsuitable (Fig. 5). In their rejection of the plans the Master and Fellows did the architect no wrong; however, an injustice was done in the way in which he was led-particularly by Jenkyns-to believe that he would be the Balliol architect right up until the publication of the official refusal in February 1843. This course of events casts a dark shadow over the Master of Balliol and sheds light on the subsequent rejection of Pugin some months later.

The Balliol incident had damaged Basevi's reputation in Oxford beyond repair:

At Oxford, where I was not unknown, I have met, most unexpectedly, my first great professional injury. . . I I can now never hope for employment at Oxford and the injury I thus sustain is irretrievable. ${ }^{11}$

The architect made two requests: that his plans should not be

10. Pugin, A Letter on the Proposed Protestant Memorial, 22-25.

11. Oxford, Balliol College Archives, MS. D.21.46; letter to Jenkyns, 24 February 1843. 


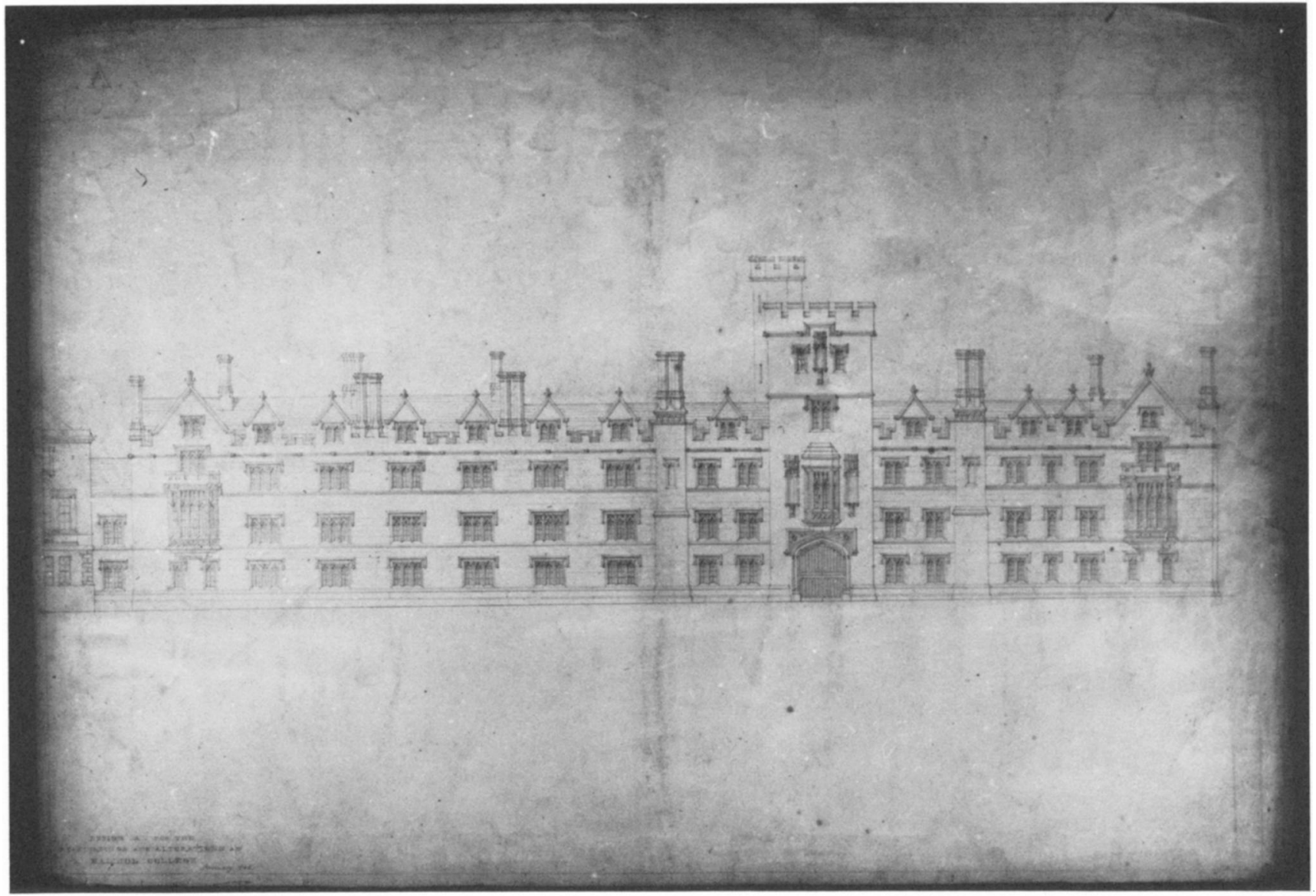

Fig. 5. George Basevi, Balliol College, Oxford, 1841, Broad Street façade. Presentation drawing by Basevi (Balliol College Archives, courtesy of the Master and Fellows).

revealed to a successor until the latter produced some originals of his own, ${ }^{12}$ and that a short delay be observed before calling in another architect, thus lending to his dismissal the appearance of a change of circumstances. ${ }^{13}$ Unfortunately neither of his requests was heeded.

Augustus Pugin's association with Balliol College began long before Basevi's rejection, and in some measure it explains the latter's fate. In 1840 Bloxam introduced Pugin to William George Ward, who was then resident in the College. ${ }^{14}$ Wilfred Ward describes the architect's reaction to a reconnaissance of W. G. Ward's quarters:

Pugin, with his love of mediaevalism, saw with satisfaction on Ward's table the Summa of St. Thomas and the works of St. Bonaventure, in huge folio volumes; and their student's enthusiasm for the Church of the Middle Ages struck a chord of common sympathy. To Pugin this signified the existence of that devotion to Gothic architecture which was in his eyes a necessary corollary following from the true Catholic spirit.

12. Ibid.

13. Oxford, Balliol College Archives, MS. D.21.55.

14. Wilfrid Ward's assertion that in 1840 Pugin was "full of a project for new Gothic buildings for Balliol College" (William George
The architect was incorrect in his assessment: Ward was not a Gothic man, as the following anecdote indicates:

After a talk with Ward one day, Pugin went to see Bloxam, and said to him, 'What an extraordinary thing that so glorious a man as Ward should be living in a room without mullions to the windows.' Next time they met Pugin taxed him with this deficiency, and received a rude shock from Ward's reply: 'What are mullions? I never heard of them.' Pugin was, however, incredulous, but on receiving a second assurance: 'I haven't the most distant idea what they are like,' he retired discomfited. A few fresh tokens of 'invincible ignorance' in architecture so shocked Pugin, that he entirely refused to believe that Ward meant what he said. 'I see how it is, my dear sir,' he said, 'you conceal your graces.' 15

Even though Ward was not as familiar with architectural principles as Pugin might have liked, he nevertheless realized that this man was the obvious choice for executing work in the Gothic style. It was clear that Balliol needed rebuilding; and while Basevi was on his way out, Pugin-through the efforts

Ward and the Oxford Movement, London, 1889, 154) seems to have no foundation.

15. Ibid. 
of the two senior Fellows, Ward and Oakley-was on his way in.

Pugin's potential selection as architect was now closer to realization. His name surely must have been familiar to the Governing Body and Master at the time Basevi's plans were being considered. It was Oakley who first, in January 1843, brought Pugin's talents to the attention of Jenkyns: "Of his great attention to his work there seems no doubt ... [he] often surprises the workmen by a sudden appearance among them when they are supposing that he is 100 miles off." ${ }^{16}$ At this point, employment as architect had not been mentioned. There then followed a letter from Jenkyns to Oakley, in which the Master referred to Pugin as "so prominent for his knowledge of Catholic architecture." $17 \mathrm{He}$ also agreed to send Basevi's drawings (on Oakley's advice) to Pugin for an opinion. Jenkyns was cautious: "But above all it must be remembered that the greatest difficulty meets us in the very limited extent of our pecuniary resources." Jenkyns ended the letter with a word of thanks to Oakley:

I cannot however close my letter to you without expressing my own obligation to you for gaining access to the best authority in the present day on the subject of the architecture, $\&$ for thus assisting in a matter in which we all feel a painful responsibility. ${ }^{18}$

After examining the Basevi designs, Pugin wrote the following letter to Oakley, on 19 February 1843, in which he candidly outlined the failings of these drawings:

Revd. Dear Sir,

I hasten to give you my unreserved judgment on the proposed additions to Balliol College which you forwarded to me. I consider them to be utterly destitute of the true and ancient spirit of design. The Fronts have evidently been composed for external effect, and the various features do not result from any internal necessity; nor are they at all expressions of the interior arrangements. In the first design I perceive some abominations - blank windows introduced in chimneystacks and an Oriel window filled out to an extravagant light in the chamber over the Gate-house. . . . The 2nd Design is free from grosser errors-but still is of the modern show school. . . . Ancient Architecture is like nature-everything keeps it place. Nothing can be ugly or offensive if it is only naturally treated.

The design you sent me might be for anything - a Blind Asylumor a Wesleyan Missionary College. . . . As to the cost, . . I would think about 10 , or 12,000 would bring out all that I would judge to be required perfectly well. At least I think I could make it do so. Waste not, spare not, is my maxim-and it's wonderful how much further money will go, when laid out on the old consistent principles.

16. Oxford, Balliol College Archives, MS. D.21.50 B; Oakley to Jenkyns.

17. Oxford, Balliol College Archives, MS. D.21.49. The fact that Jenkyns used the word "Catholic" instead of the expected "Gothic" might serve to indicate the first signs of future friction between the Master and Pugin.

18. The subscriptions had only accounted for a portion of the 10,000 pounds required for the building restorations.
Pugin also disapproved of Basevi's suggestion to move the Master's Lodgings:

When the Abbots ceased to reside with their communities and built separate lodgings, the rule and spirit was fast going to decay. And I believe the same remark is applicable to collegiate discipline. ${ }^{19}$

In this statement, Pugin showed that his criticism went beyond the aesthetic failings of the drawings: he had identified architecture with moral values and, by extension, with the Roman Catholic faith.

The above letter, with his comments on the drawings, suggests that Pugin considered himself a suitable replacement for Basevi, who was officially rejected on 23 February 1843. On 19 February Pugin informed his patron, Lord Shrewsbury, that he had "every confidence that a very important job at Oxford will be put into my hands"; ${ }^{20}$ however, he had no idea that a heavy restriction would be placed upon him: he was to execute the designs but could have no hand in the creation of the buildings. The condition was imposed by Jenkyns, the anti-Tractarian and anti-Catholic. It had been but three years since Pugin had written $A$ Letter on the Proposed Protestant Memorial; the statements made therein were not quickly forgotten by the Oxford authorities. The architect had a very definite idea regarding the form to be taken by a college erected on a Roman Catholic foundation; and with his Tractarian supporters, Ward and Oakley, Pugin hoped to realize his aim. The conflict was to become one not merely of architectural styles but, more importantly, one of religious politics.

Richard Jenkyns wielded considerable power in the College, and was not prepared to give Pugin official recognition as architect of the rebuilt Balliol. In the English Register the following minutes were recorded for a College Meeting of 6 March 1843:

Several discussions having before been held, when the Master had declared his own views, which were decidedly adverse to those of the Fellows, respecting the best mode of proceeding in the renovation of the front of the College, and various proposals having been made, it was agreed that Mr. Pugin be requested to furnish a design for a new facade towards the Broad Street but at the same time resolved that under the peculiar circumstances of the case, even if Mr. P.'s plan should eventually be approved and be thought worthy of being carried into effect, he himself not be employed in the execution of the work. ${ }^{21}$

Understandably, Pugin was perplexed by the imposition of such conditions:

19. Oxford, Balliol College Archives, MS. 21.50 A.

20. Quoted in P. Stanton, "Welby Pugin and the Gothic Revival," $\mathrm{Ph} . \mathrm{D}$. thesis, University of London, Courtauld Institute of Art, 1950, 370.

21. J. Jones, “The Civil War of 1843," Balliol College Annual Record, 1978, 63. 


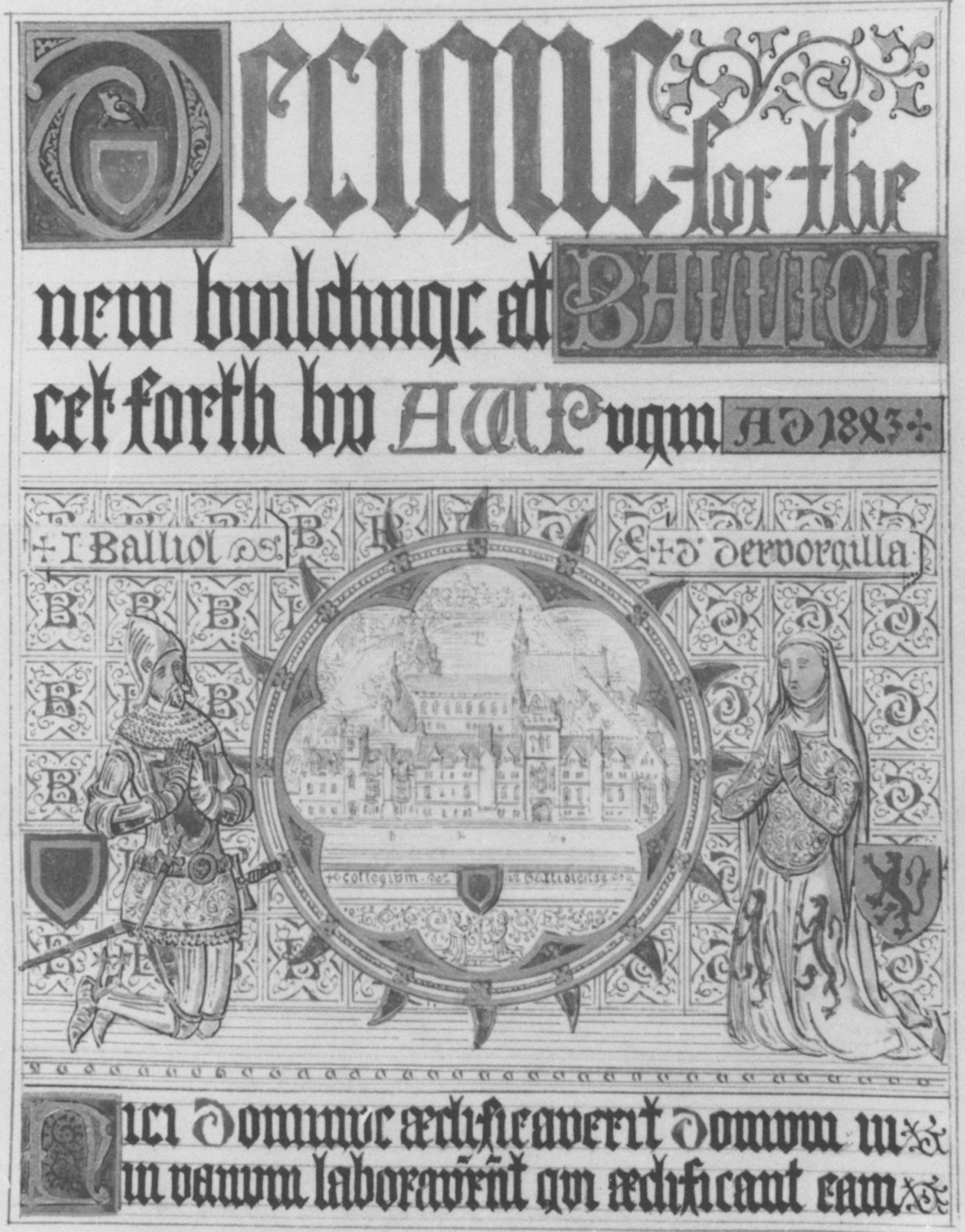

零

Fig. 6. Augustus Welby Northmore Pugin, Balliol College, Oxford, 1843. Frontispiece of Pugin's volume of drawings. The founder and foundress, John de Balliol and his wife Dervorgilla, kneel on either side of a miniature of Pugin's design (Conway Library, Courtauld Institute of Art, London). 


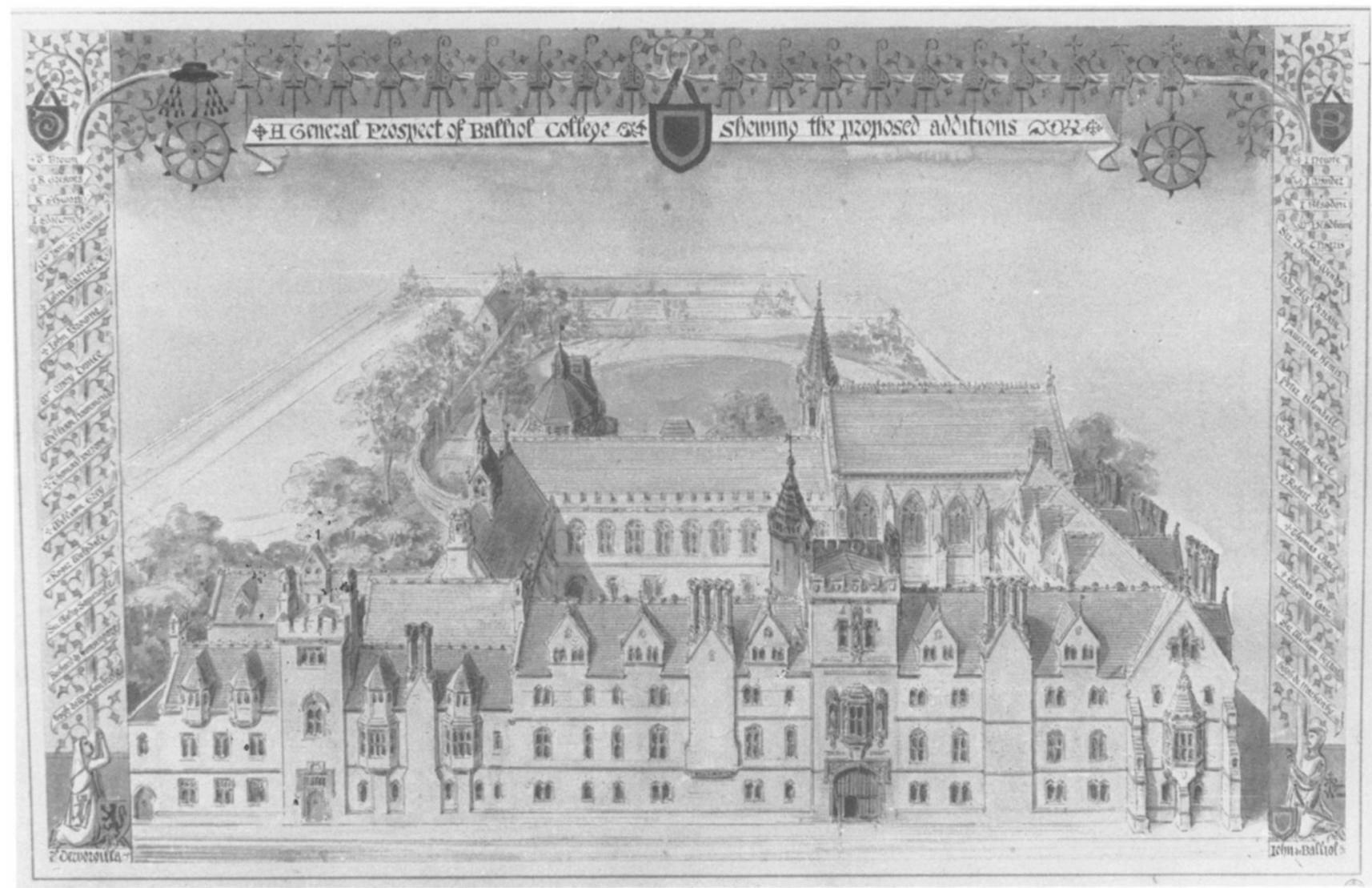

Fig. 7. A.W.N. Pugin, Balliol College, 1843. "A General Prospect of Balliol College, shewing the proposed additions" (Conway Library, London).

I have just had a most perplexing letter from our friend Ward. I hardly know what to do, or what he wishes me to do-the idea of transferring my designs to another architect is quite unbearable $\&$ such a man as is mentioned a poor tool indeed, without information or ideas. The Balliol men have been so kind, I do much to get them out of their present painful position but this amounts to a sort of suicide \& I do not think I ought to consent. ${ }^{22}$

Nevertheless Pugin thought it a project of great importance: even if he did not carry out his plans, he thought that the proper Catholic spirit which he instilled into the plans would be transferred to the stones. Soon after Jenkyns handed down the decision, Pugin wrote to Bloxam:

I received a letter from $\mathrm{Mr}$. Ward by the same post as yours, \& I must hardly tell you that the intelligence was as unexpected as gratifying. I quite agree with you, that it is not a case where I ought to stand on conditions but make the best of it, as it may be a great means by the blessing of God of reviving the real spirit of antient [sic] collegiate architecture. I shall enter on this work with all possible energy, for working on the old foundation is most inspiring, \& above all in such a locality as Oxford. I shall probably have to come down for a day to examine the present buildings $\&$ get necessary instructions. . . I I think

22. Oxford, Magdalen College Archives, MS. 528, letter no. 53; to Bloxam, from Kilarney, St. John's Day (5 March), 1843. you will give me some credit for my silence when I was last at Oxford about the communication I had from Ward, but I did not venture to entertain a hope that it would be attended with any result as regarded myself. $^{23}$

Jenkyns then struck the next blow; but this time it was not only against Pugin: it was in opposition to the Fellows. The Master had already agreed in principle to the employment of Pugin, if only for the designs; however, on 13 March he changed his mind: he expressed his opposition to the execution of any design by the Roman Catholic architect:

After a careful consideration of the language and spirit of our Statutes, and under a strong sense of obligation imposed on the Master by the terms of the oath taken at his admission, I am compelled to declare that I can neither sanction the employment of Mr. Pugin as an Architect, nor consent to an agreement for carrying into effect by him, or any other Party, any plan which he may furnish for repairing that part of the College in which the house, of right belonging to me, is situate.

I am resolved, and I am desirous of stating my resolution calmly, and deliberately, but with firmness, to withhold my consent to affixing of the College seal to any instrument for sanctioning the execution of a work under the circumstances and conditions already

23. Oxford, Magdalen College Archives, MS. 528, letter no. 97; from London, Feast of St. Thomas Aquinas (7 March), 1843. The letter from Ward was presumably the one informing Pugin that he had secured the post of architect. 


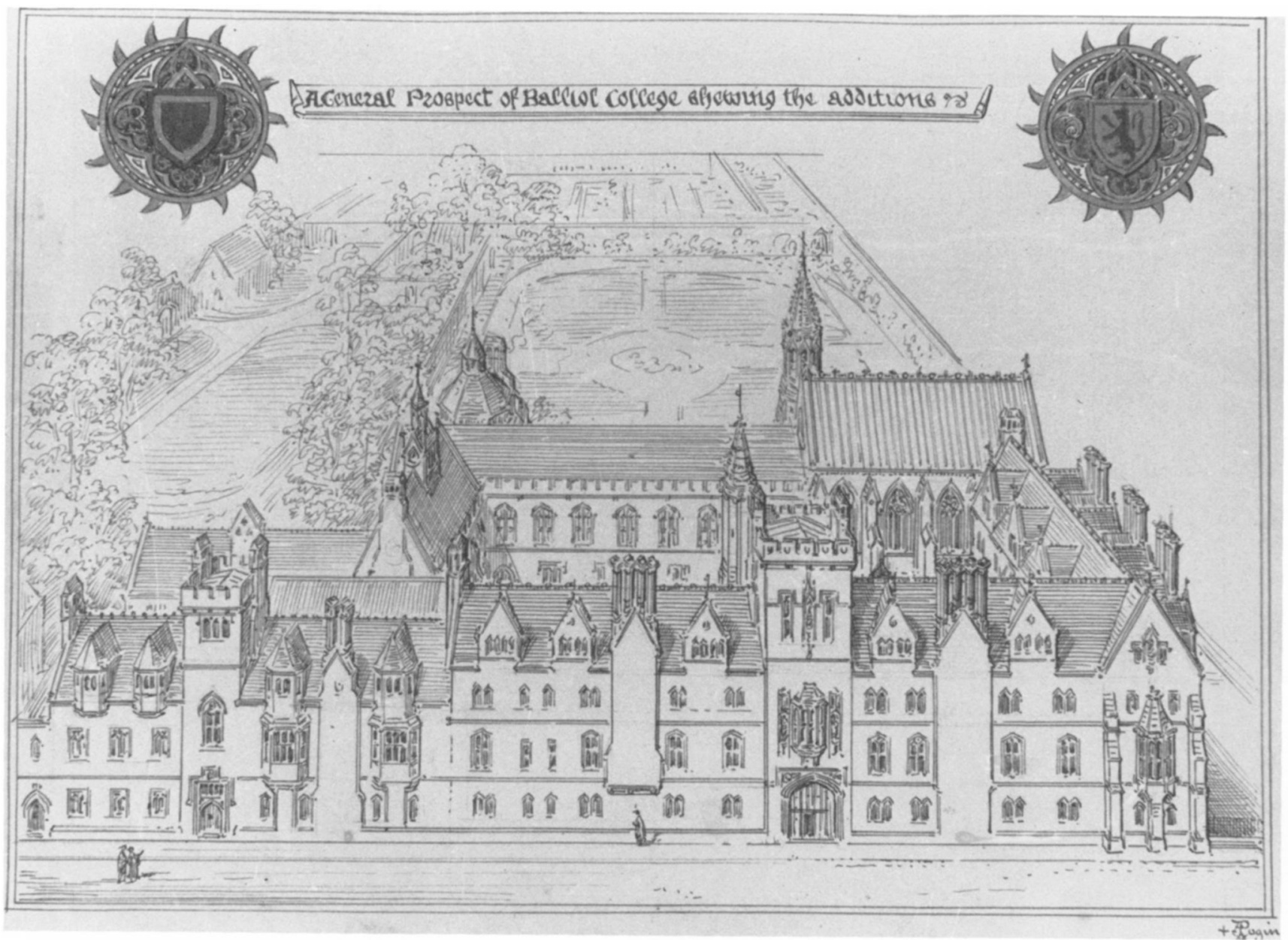

Fig. 8. A.W.N. Pugin, Balliol College, 1843. "A General Prospect of Balliol College shewing the additions" (Conway Library, London).

mentioned. And I beg to explain that no grave matter of College business, beyond such affairs as are expressly regulated by Statute, can be legally transacted without authority under the seal of the Body consisting of the Master and a majority of the Fellows.

After this declaration I have only to call upon the Fellows to cooperate with me in such repairs of the existing buildings as the indefinite delay of the work lately projected, may render necessary. ${ }^{24}$

In making the above declaration, Jenkyns had effectively vetoed the whole scheme; but the Fellows were still determined not to accept designs by any other architect: they were undeterred by Jenkyns's statement and, without the Master's consent, encouraged Pugin to go ahead with the designs. ${ }^{25}$

On 27 March Pugin wrote to Bloxam from London: "I have returned to town and am working away at the Balliol draw-

24. Oxford, Balliol College Archives, MS. D.21.54.

25. According to both Jones ("Civil War," 62) and H. M. Colvin (Unbuilt Oxford, New Haven and London, 1983, 109), Pugin had executed the designs by the time Jenkyns had called the special meeting of 13 March; however, as the dates of Pugin's letters regarding the preparation of the plans demonstrate, they were executed toward the end of March 1843. ings. Mr. Ward promised to procure for me the Master's arms and motto which I wish to introduce"; ${ }^{26}$ and in another letter from Alton, "I am going home to work as hard as possible for Balliol." 27 In fact Pugin pushed himself to the limit in the production of these plans. Ferrey records that two clergymen called one morning at his house in Chelsea, asking to see the Balliol plans. They found

not merely the usual architectural drawings for a new chapel, gateway and rooms, but large perspective drawings of all these in water colours-interiors as well as exteriors-lining the entire walls of his room.

26. Oxford, Magdalen College Archives, MS. 528, letter no. 108. Pugin might have introduced Jenkyns's arms in an attempt to please him; by this time the architect must have been painfully aware of the Mastcr's opposition to him.

27. Oxford, Magdalen College Archives, MS. 528, letter no. 110. 


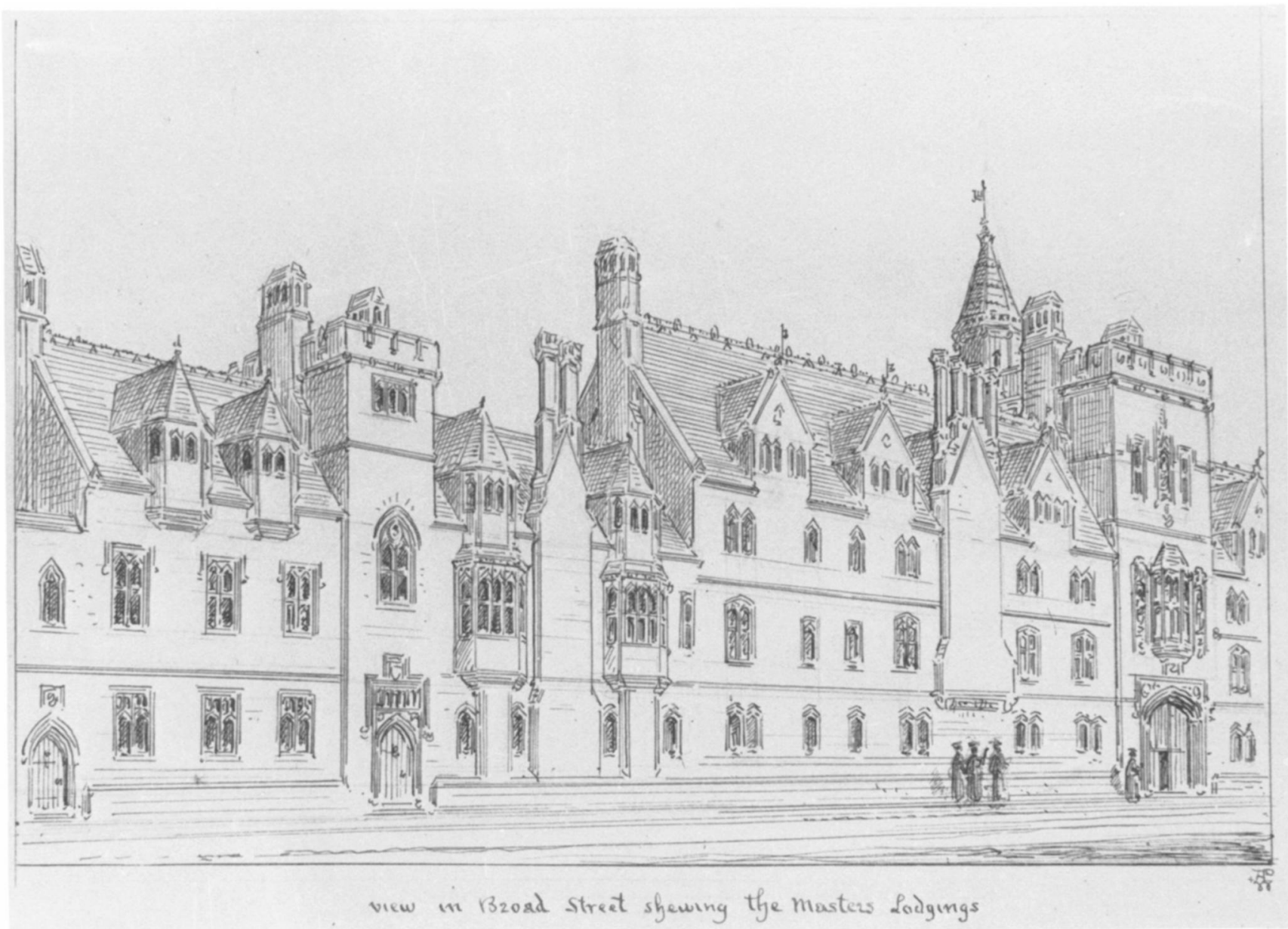

Fig. 9. A.W.N. Pugin, Balliol College, 1843. "View in Broad Street shewing the Master's Lodgings" (Conway Library, London).

These were plans, elevations, and sections intended for the Governing Body; but there was also another set of designs:

He was then amusing himself with a book with the most beautiful finished outlines of all these drawings. This book he designed for a present to Mr. [William] George Ward, the fellow of the College to whom he owed his appointment as architect to the new buildings.

This set of designs, which resides in the Balliol College Archives, was bound like a missal, with gilt clasps and an illuminated title page; it was obviously painstakingly executed (Figs. 6-15). To complete all of these drawings in less than a fortnight was a Herculean achievement. Ferrey records that when asked by the two clergymen why he did not give the mere mechanical portion of his drawings to a clerk to produce, Pugin retorted, "Clerk, my dear sir, clerk, I never employ one; I should kill him in a week!" 28

Even for a man of Pugin's energy and determination the execution of these drawings, complete with detailed estimates of the cost involved, in such a short time, was an impressive

28. Ferrey, Recollections of Pugin, 187. feat. He described his state during their composition in a letter to Bloxam:

You have no idea how I have worked at these designs. I have never exerted myself so before, for I quite delight in this opportunity of setting forth real collegiate architecture. On Friday Mr. Oakley comes to see the designs before they are sent down. I shall sing a Te Deum in this season when they are finished, for it is a great work to design and estimate every detail of such a building, \& I have had so little time, not clear 2 weeks.

While I was arranging the plan, I got excited beyond my strength \& could neither eat nor sleep but I am now better. I have got all the rooms perfectly convenient \& the master's lodgings will set you half mad for true Christian rooms. I shall expect to see you mullioning your sashes. ${ }^{29}$

Pugin sent the drawings to Balliol on 8 April. ${ }^{30}$ Shortly after dispatching them he wrote to Bloxam with final thoughts on the fruits of his labor:

29. Oxford, Magdalen College Archives, MS. 528, letter no. 100; postmarked 4 April 1843.

30. Oxford, Magdalen College Archives, MS. 528, letter no. 92: "The drawings are all gone to Balliol." 


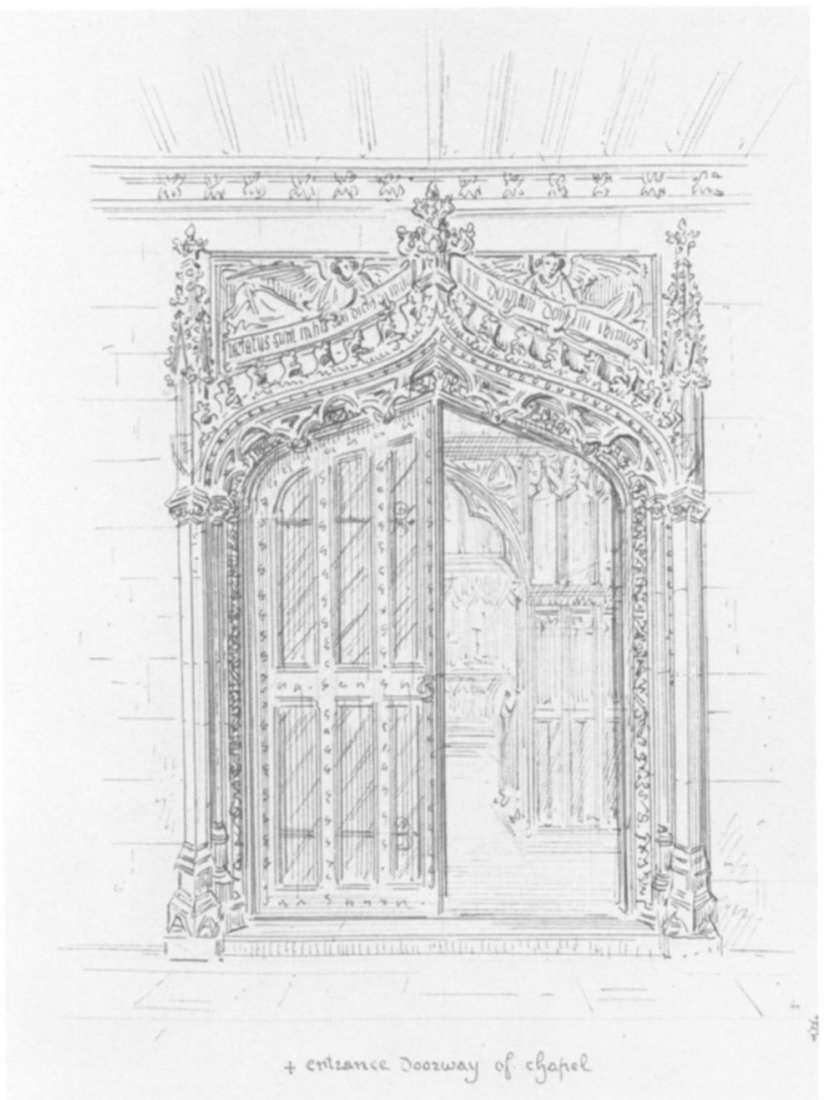

Fig. 10. A.W.N. Pugin, Balliol College, 1843. "Entrance doorway of chapel" (Conway Library, London).

I am almost beyond my strength. I have never felt so much overcome as with finishing the Balliol drawings. The subject was naturally so exciting, working on one of the old Buildings seemed almost too delightful to bear \& I could scarcely sleep while the design was in my hand. ... It must do good. I have gone into every detail, convenience, \& necessity, dictated every feature-there is nothing whatever artificial about it. I have done so much that I almost fear it will be suspected I began before I read the order of the College, but I can assure you that every drawing ... was made by my own hands between last Tuesday week \& this morning without any assistance whatever. Of course I had plenty of help in estimating the expense \& I have got the cost out most accurately. . . . You will be ill with pleasure when you see the old collegiate buildings set forth in all their glory, \& when we reflect what sums have been thrown away in vile erections one could almost curse \& swear. ${ }^{31}$

Meanwhile, in Oxford, the war was escalating. The Oxford Chronicle and Reading Gazette had heard that Pugin was being considered for the position of architect at Balliol, and on 18 March ran the following article:

31. Oxford, Magdalen College Archives, MS. 528, letter no. 93; from London and Birmingham.

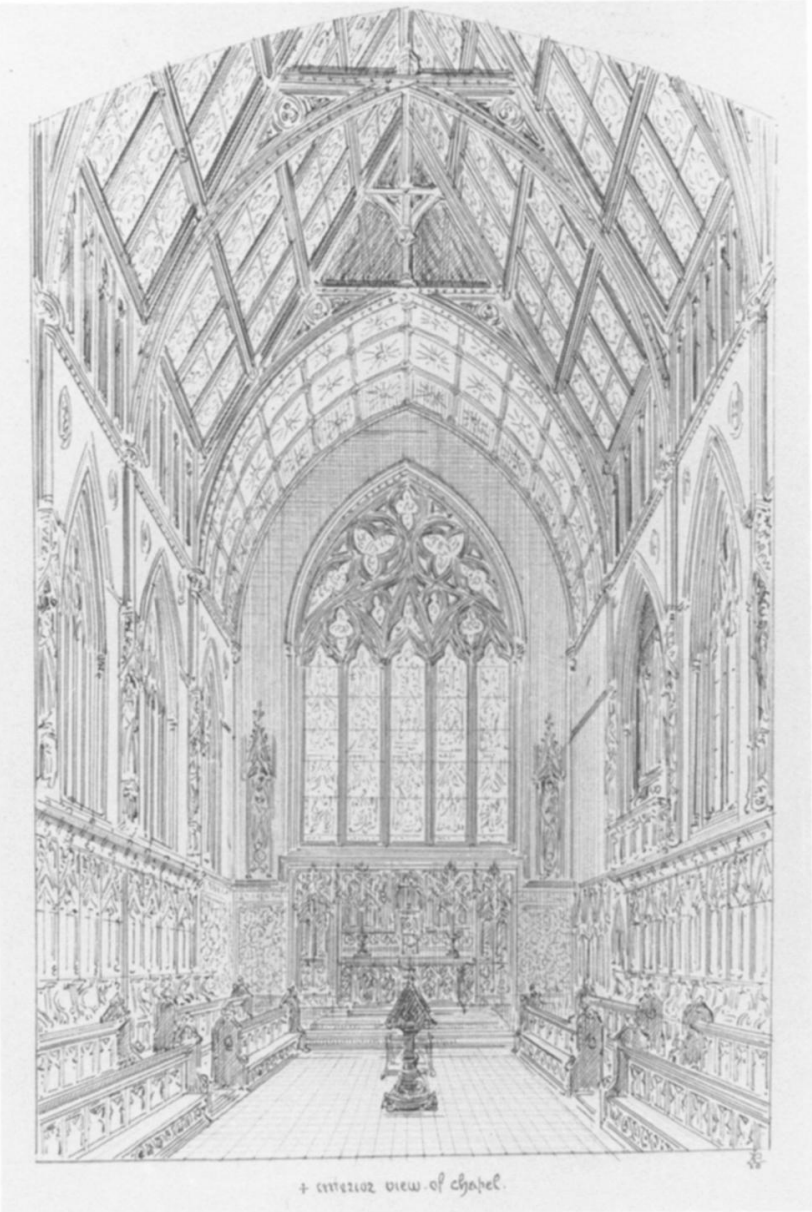

Fig. 11. A.W.N. Pugin, Balliol College, 1843. "Interior view of chapel" (Conway Library, London).

\section{EXTRAORDINARY LIBERALITY}

Mr. Pugin . . . is at present on a visit to the Master and Fellows of Balliol College, having been selected to design the extensive restorations now in contemplation at Balliol College. This no doubt is intended as a pointed and double amende to the Roman Catholics on account of the Martyrs' Memorial. Mr. Pugin wrote bitterly against the memorial, and he is now employed to set up restorations over against it at the very college whose walls reflected the martyrs' fires.

On 25 March another article appeared:

We have received a communication from a senior member of the University, who informs us that Mr. Pugin's recent visit to Balliol College was at the invitation of the Tractarian Fellows and Tutors of the College, not only without sanction, but in opposition to the express wishes' of Dr. Jenkyns, the Master. Our correspondent also states that the latter functionary has placed his express veto on the appointment of Mr. Pugin as architect, and that 'the unprincipled mover in the intrigue is for present doomed to disappointment.' In expressing our satisfaction that the Master of Balliol College has (though not it seems till the society over which he presides is thoroughly corrupted) become more sensible of the responsibility imposed upon him, we must not be understood to condemn ordinarily 


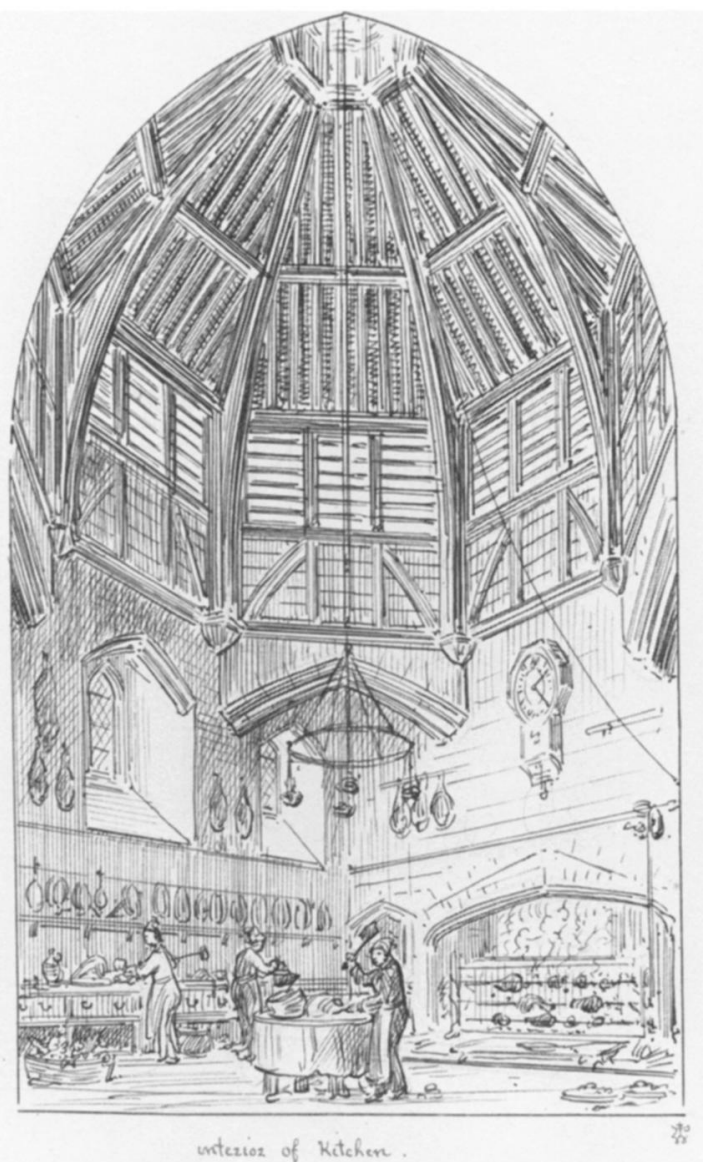

Fig. 12. A.W.N. Pugin, Balliol College, 1843. "Interior of kitchen." This building was based on the Abbot's Kitchen at Glastonbury (Conway Library, London).

the employment of professional men without reference to their religious tenets. But at the present juncture, the employment of a gentleman who has outraged nineteen twentieths of our countrymen by writing down Protestants as 'canting hypocrites, and raving fanatics, the Reformers as apostatizing, church plundering, crafty villains; the subscribers to the Martyrs' Memorial as foul revilers, tyrants, usurpers, extortionists, and liars; and the Protestant Church of these realms as a gross political imposition,' can be but viewed as an awful testimony to the faithlessness and apostasy in the university.

It is not unlikely that Jenkyns himself was the correspondent. The Master was certainly doing all he could to fuel the fire between himself and the Fellows.

Jenkyns's criticism of Pugin takes on a different appearance when one realizes that Jenkyns had been a subscriber to the Martyrs' Memorial and therefore could have harbored a personal grudge against the architect. This heightened animosity which Jenkyns must have felt incited him to take a more practical step toward ensuring that Pugin's plans were not executed: he withdrew his own name and those of his family from the list of subscribers to the Balliol refurbishment.

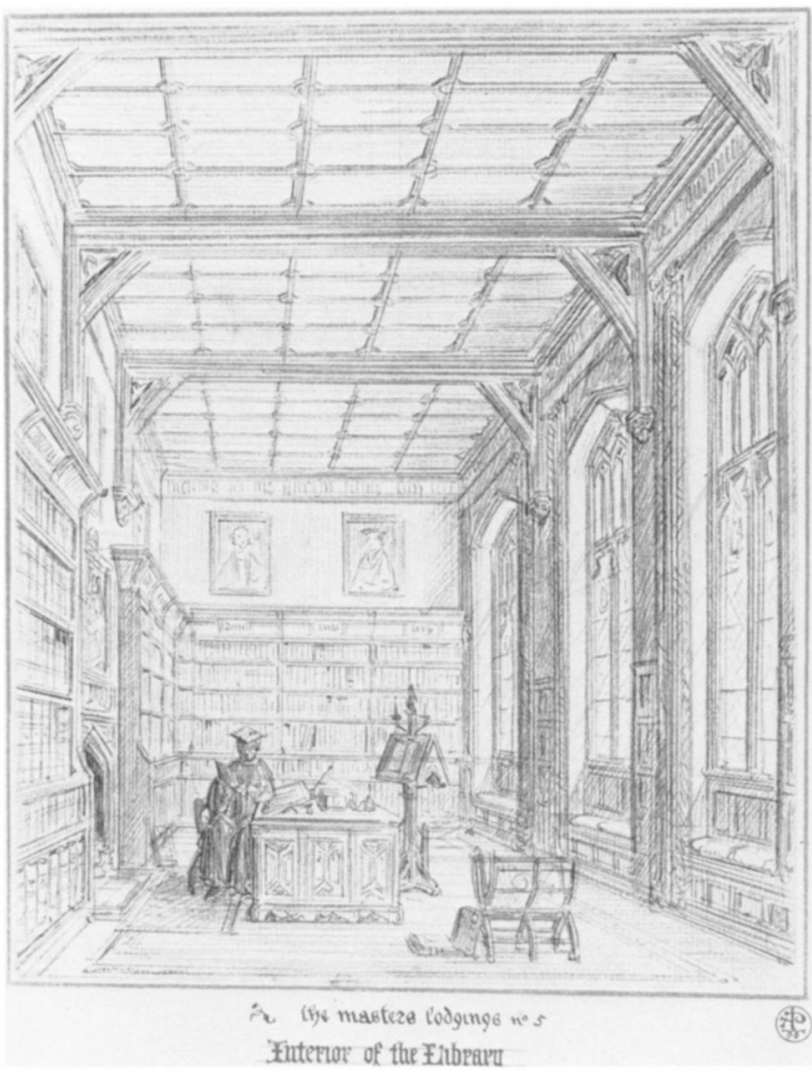

Fig. 13. A.W.N. Pugin, Balliol College, 1843. The proposed library in the Master's Lodgings (Conway Library, London).

The articles in the Oxford Chronicle certainly drew much attention to the Master and Fellows of Balliol. Jenkyns might have thought that the undesirable publicity would incite the Fellows who supported Pugin to abandon their cause; instead, their desire to see Pugin reinstated as architect grew. The following pronouncement resulted from a College Meeting held on the day after the second article appeared in the Oxford Chronicle.

We, the undersigned, being all the Fellows assembled at a College Meeting held on Mar. 26 on the subject of the Building declare that the proposal to employ Mr. Pugin, in carrying out his own designs was intended chiefly to meet the Master's objections to that Gentleman, and that should the Master refuse that cooperation which such a compromise was understood by us all to imply, we consider ourselves justified in honour, as we are so in form, to enter into such ultimate arrangements as may seem best to us for completing the scheme.

$$
\begin{aligned}
& \text { W.G.W. [William George Ward] } \\
& \text { E.C.W. [E. C. Woolcombe] } \\
& \text { B.J. [Benjamin Jowett] } \\
& \text { H.W. [Henry Wall] } \\
& \text { E.K.K. [E. K. Karslake] }{ }^{32}
\end{aligned}
$$

32. Oxford, Balliol College Archives, MS. Jenkyns I. 


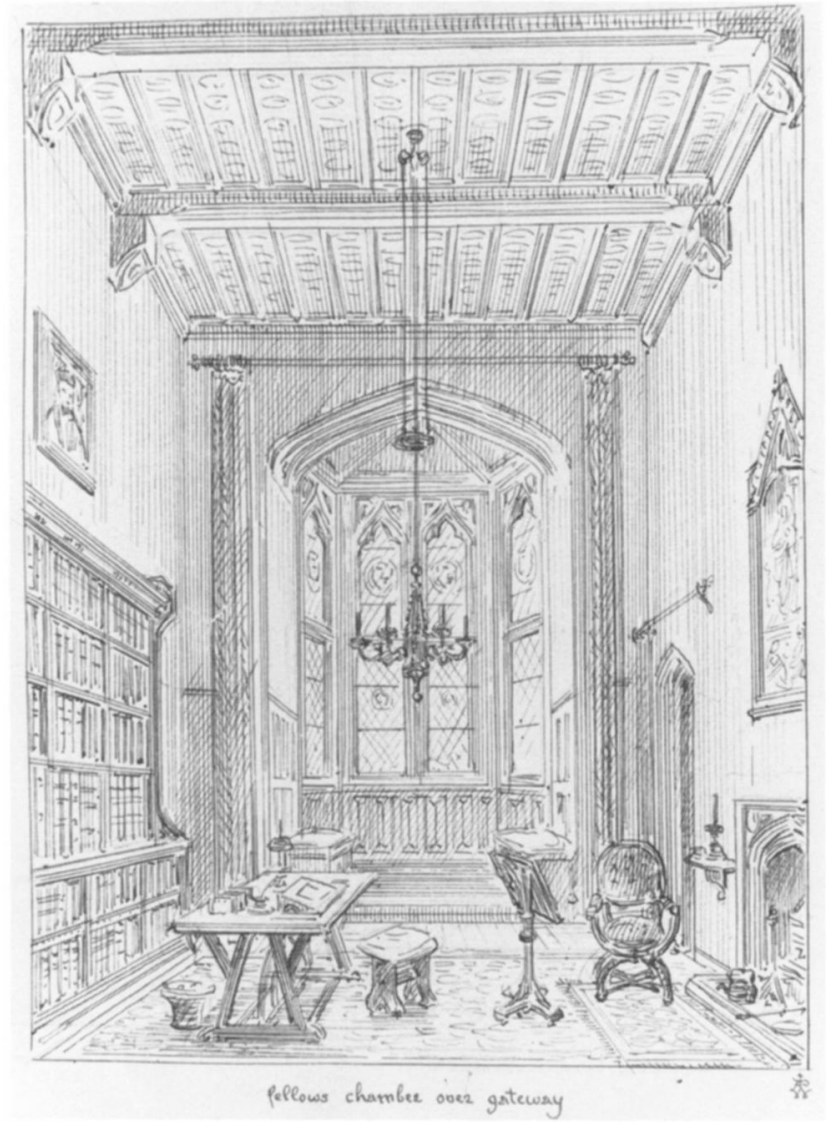

Fig. 14. A.W.N. Pugin, Balliol College, 1843. A Fellow's chamber over the gateway (Conway Library, London).

In a letter to Bloxam of about the same time Pugin accused Jenkyns of personal animosity toward him: "I cannot conceive who can have come against me from Balliol except the Master, as the Fellows have always appeared most friendly." ${ }^{33}$ In the same correspondence Pugin offered the same complaint as Basevi: he was unaware of any doubt about his being appointed architect of Balliol: "I would not enter into anything like a competition on any condition for obvious reasons." The reasons become obvious when one considers that in 1843 Pugin was overwhelmed with work, and so well known that he no longer had to seek employment. He would scarcely have prepared two such elaborate sets of designs in the mere hope that the College might appoint him: he must have been given a more substantial assurance of his selection.

By the beginning of April the controversy had become so violent that Jenkyns thought it prudent to remove from the English Register two pages recording some of the most heated debates in Balliol's history. The action by Jenkyns was one which the Fellows condoned:

33. Oxford, Magdalen College Archives, MS. 528, letter no. 73 ; undated.

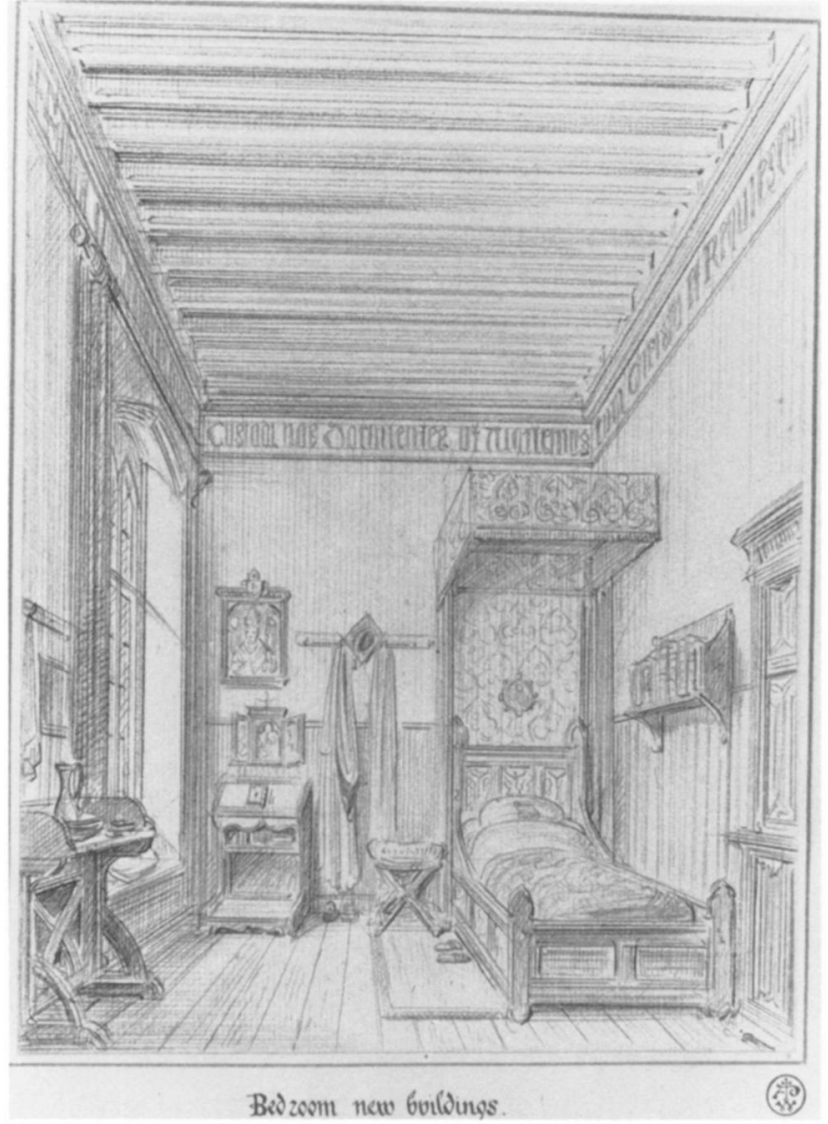

Fig. 15. A.W.N. Pugin, Balliol College, 1843. Pugin's idea of an undergraduate's room (Conway Library. London).

At a meeting on Saturday, April 1, the Fellows were willing to consent to the removal of the two first papers from the College Register-but would retract no part of their document-\& would agree only to suspend the execution of Mr. P.'s designs in deference to my scruples.

Such is the present posture of affairs. ${ }^{34}$

Understandably they consented to the removal of the pages in question for the sake of Balliol's reputation, and not to destroy any record of the Master's role in the controversy.

The Balliol Fellows were not easily assuaged; they were still incensed by Jenkyns's unconstitutional veto. Not wishing to break with protocol, the Fellows submitted a formal memorial through the proper channel of the Senior Fellow, Oakley, who acted as a neutral intermediary. Unfortunately, this expression of displeasure incensed Jenkyns and did not sway him in the least. The memorial served to widen the rift between Master and Fellows. Although it might be assumed that the two Senior Fellows were the leaders of the campaign to have

34. Oxford, Balliol College Archives, MS. D.21.57; memorandum by R. Jenkyns. 
Pugin reinstated, John Dobree Dalgairns, ${ }^{35}$ in a letter to a friend, on 3 April 1843, observed that Ward and Oakley were not the most outspoken protesters in the architectural dispute:

There is a great shindy at Balliol. You must know the Master's house is tumbling down and the whole College is in a rickety state. The Fellows determine to have Pugin to repair or rather to rebuild it, and actually bring over the Master, so that Pugin was actually engaged and came down to take the measurements. In the meantime that source of all mischief Golightly takes the alarm and communicates his alarm to the Master, who determines not to have Pugin. On which the Fellows run rusty and refuse to rebuild the Master's house and there ends the matter for the present. The best of the joke is that the leaders among the Fellows are by no means Ward and Oakley, as you might suppose, but all the set who turned out or helped to turn out old Ward of his tutorship. ${ }^{36}$

The entire controversy was officially settled on 4 April 1843 at a College meeting:

Difficulties have arisen, and various discussions on those difficulties having taken place, it was agreed to abandon for the present the intended designs for restoring the front of the College.

That in the meantime the dilapidated roofs of the Buildings be put in a safe and proper condition under the direction of a competent builder.

That the building committee formed June 3, 1842, be dissolved.

That a communication be made to those friends of the College who have either contributed, or expressed an intention of contributing money towards the restoration and beautifying of the front of the Building towards the Broad St., \& that they be informed with a great sense of their kindness, that as the purpose for which their contributions were intended, is for the present abandoned, the Master \& Fellows decline availing themselves of their liberality. ${ }^{37}$

This meeting dashed any hopes of appointing Pugin as architect. Nevertheless the Oxford Chronicle engaged in yet another attack on the architect. On 22 April 1843 the following article appeared:

\section{INTRIGUES AT BALLIOL COLLEGE}

The Newman Paper $^{38}$ has the following reference to the proposed improvements at Balliol College:
Important improvements, and alterations are about to be made in some of the buildings of Balliol College which in the lapse of years have become unfit for residence, and out of harmony with the improving character of the neighbouring structures. Various designs, it is said, have been submitted to the Master and Fellows, but nothing is yet decided on.

The above statements are obviously designed to mislead. Mr. Pugin's measurements have been taken and his plans prepared, but last week the Master of this College having succeeded, with the cooperation of the non-resident Fellows, to cancel the agreement for the employment of that gentleman as architect, the Tractarians are now aiming at the postponement of the execution of the proposed improvements, until the consent of the majority can be obtained to the adoption of Mr. Pugin's plans.

The above facts were spurious. The Fellows knew full well that there was no longer any hope of having Augustus Pugin appointed as architect. The article was simply another opportunity to mount an attack against Pugin, because of his Catholicism and his Letter on the Proposed Protestant Memorial, and against the Tractarians, who were thought to have supported Pugin in his efforts.

For Pugin the matter could not yet be laid to rest: he had received no remuneration for the diligent work which he put into the project. He wrote to Bloxam from Ramsgate:

To put an end to the Balliol dispute, I have offered to let them off by paying my actual expenses. I hope they will agree to this, for I detest corresponding on unpleasant matters. It makes me ill. ${ }^{39}$

It seemed that the College wished to retain the drawings, but haggled over the price. The protracted dispute lasted two years, and in 1845 Pugin informed John Hardman that he would now lose "a great part if not all the Balliol money after all"; he went on to say that taking the matter to law would be too costly, and that he had lost a great deal of money over the drawings. Later in the same year, the matter was settled. Pugin wrote to Hardman to say that he was going to do better with reference to Balliol than he had at first thought.$^{40} \mathrm{He}$ also wrote to Bloxam:

The Balliol people have at last written to me to say they will not pay me the amount for the designs and require me to make an abatement,

young undergraduates and eventually pressured Ward into resigning his tutorship in 1841.

37. Ibid.

38. The British Critic seems to be the only publication that could fit this description; but it contains nothing about Pugin's dealings with Balliol.

39. Oxford, Magdalen College Archives, MS. 528, letter no. 36, 1843.

40. Stanton, "Welby Pugin and the Gothic Revival," 371.

41. Oxford, Magdalen College Archives, MS. $\Sigma 28$, letter no. 67; no date or place of origin, but presumably from 1845 . 


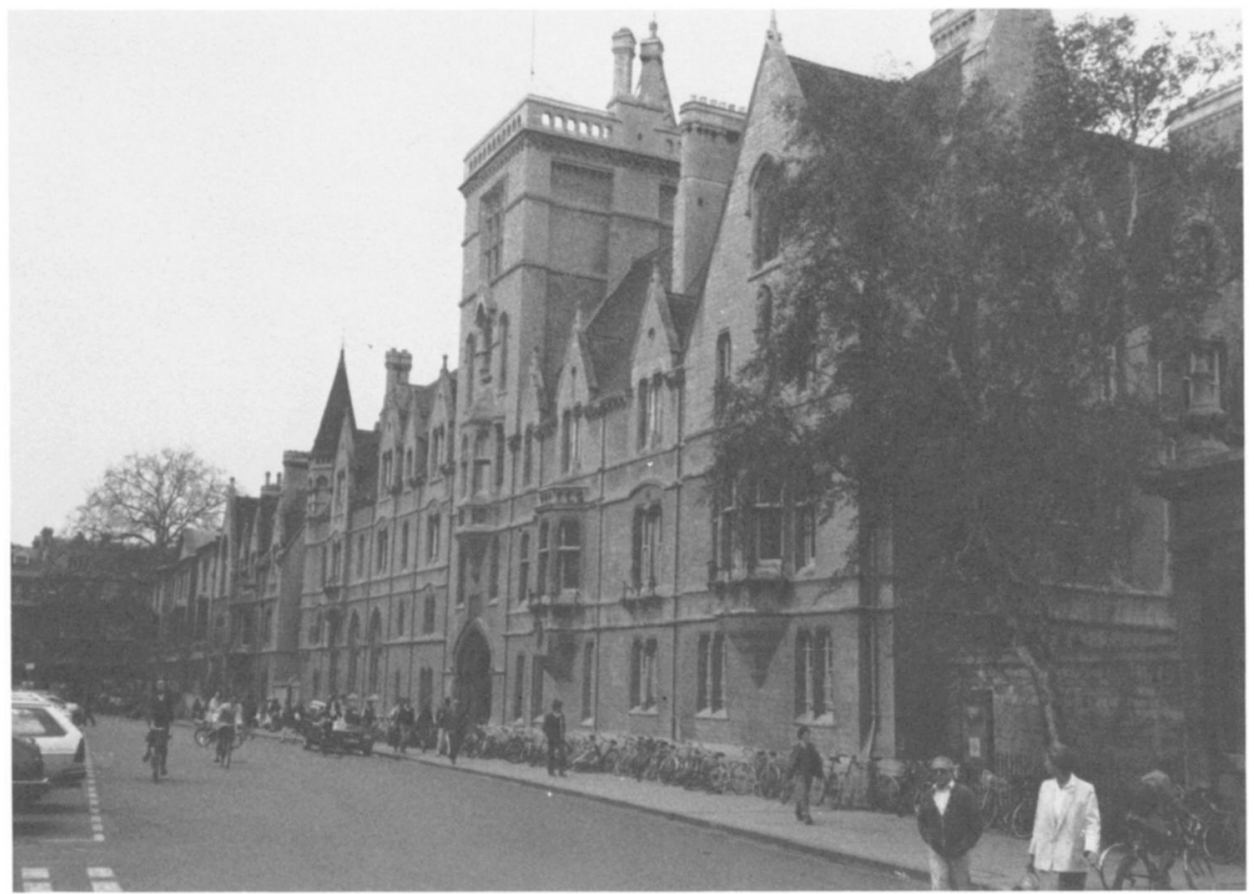

Fig. 16. Alfred Waterhouse, Balliol College, 1867-1868. The present Broad Street façade (author).

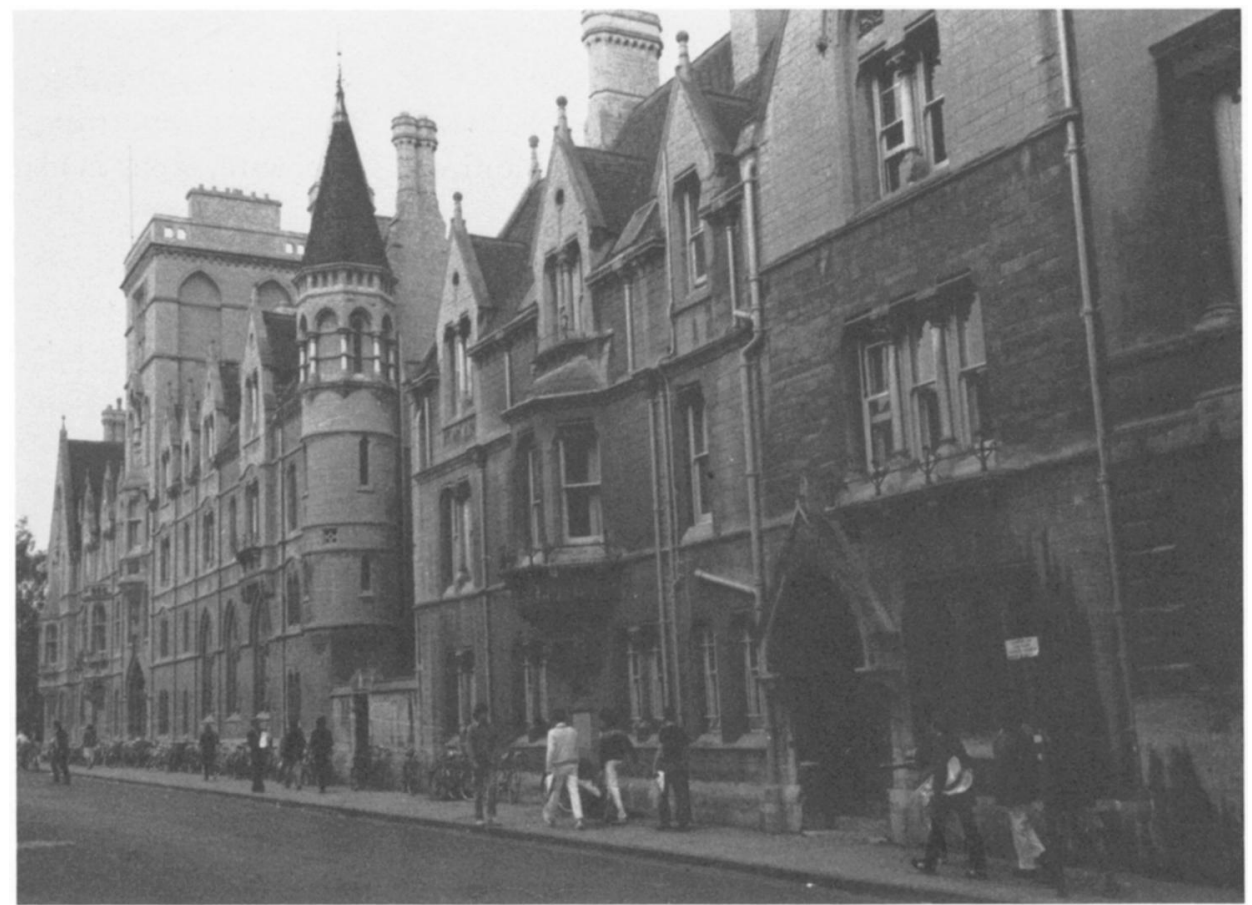

Fig. 17. Alfred Waterhouse, Balliol College, 1867-1868. The present Broad Street façade, showing the Master's Lodging on the left (author). 
that is the very word. I feel quite indignant about it. I have paid more that $2-3$ rds of the charge in expenses. They have kept me 2 years and now write in that way. I would rather give up everything than abate a shilling. It has been nothing but trouble and expense to me. ${ }^{41}$

Pugin was, in the end, paid by the College; even though there is no record of the exact amount it was surely less than what the architect expected-or deserved-for his efforts.

Pugin did not lack for employment in the early 1840s: it was a period which saw the erection of a great many Roman Catholic edifices by this architect; yet he consented to a request to redesign the buildings of a Protestant college. He considered the Balliol refurbishment a prime opportunity to instill true Catholic spirit into a city that had been dominated by the Established Church since the Reformation, a city that "at a distance, presents a complete grove of towers, spires, and pinnacled turrets." 42 In Pugin's mind the rebuilding of Balliol would have been a great victory for English Catholicism; unfortunately for him, his efforts were not given the recognition that they merited.

It should be mentioned that the sphere of rejection extended outside Pugin himself to include the builder employed by the architect for most of the edifices which he designed: George Myers. In a letter to Bloxam of 1850 , Pugin noted that the "miserable failures" he had experienced resulted in reluctance on the part of the Oxford authorities to employ Myers. ${ }^{43}$

In adherence to the directions of the English Register, only minimal repairs sufficient to prevent the collapse of the Master's Lodge were carried out. The only building that occurred during Jenkyns's lifetime was carried out in 1852-1853 by Anthony Salvin, who built the present Salvin buildings. ${ }^{44}$ Nothing more was done until after Jenkyns's death in 1854 , when it was decided to rebuild the chapel as a memorial to him. William Butterfield was employed, and carried out the work in 1856-1857.45 Meanwhile Pugin's designs remained in the College Library. By 1866, through a substantial donation from Miss Hannah Brackenbury, the College acquired sufficient funds to make the rebuilding of the front quadrangle feasible. They employed Alfred Waterhouse in 1867-1868 to do the job. ${ }^{46}$

Before Waterhouse began work Pugin's plans were lent to him-just as Basevi's had been given to Pugin. ${ }^{47}$ Waterhouse approved of the designs; he measured them, made tracings, and in broad outline followed their inspiration for the front of the College (Figs. 16, 17). Though the Balliol dispute had been nothing but trouble for Pugin, perhaps partial reparation was made by the fact that something of his spirit still found expression in the Broad Street façade.

It is significant that Waterhouse consulted Pugin's designs: it attests to the influence Pugin had on the Oxford architects who followed him. The Balliol incident was without a doubt Pugin's most acutely felt failure at Oxford. The architect never designed any significant edifices in "the city of spires," partly because of his allegiance to the Roman Church and his support of the Oxford Movement, but more significantly because of his vexatious criticism of the Martyrs' Memorial and the Established Church in general. Even given the significance of this defeat, the overall impression left by Pugin on Oxford might be that of success. He was the acknowledged leader of the Gothic revival in England, and his love of this particular style was passed on to many important architects, including Waterhouse, Butterfield, Bodley and Garner, Deane and Woodward, Scott, and Street. ${ }^{48}$ These successors all contributed to the impression of Oxford as "a complete grove of towers, spires, and pinnacled turrets." ${ }^{49}$ In their work one can plainly see the influence of Augustus Pugin in Gothicizing this city. Despite this personal failure at Balliol, it is readily apparent that "defeat" is not the word that best describes the wider result of this architect's efforts at Oxford.
42. A.W.N. Pugin, The True Principles of Pointed or Christian Architecture, London, 1841, 60.

43. Oxford, Magdalen College Archives, MS. 528, letter no. 153; from St. Augustine's.

44. Trappes-Lomax notes that a touch of irony was added by the fact that this Protestant architect had been less successful in an earlier endeavor: the competition for the new Houses of Parliament, which was won by the designs made by Pugin and Charles Barry ( $M$. Trappes-Lomax, Pugin: A Mediaeval Victorian, London, 1932, 140).

45. Colvin describes the structure as "a building as redolent in its way as Pugin's of the High Churchmanship which Jenkyns had so resolutely opposed" (IJnbuilt Oxford, 111).
46. Waterhouse was a Quaker; however, by the late 1860s architectural style and religious belief were no longer so closely allied. The Balliol façade was his first Oxford commission.

47. The plans were lent also to Edward Pugin in 1861 for a memorial exhibition of his father's work.

48. The most significant Gothic buildings included Deane and Woodward's University Museum (1855-1860), Waterhouse's Balliol refurbishments (1856-1857), and Butterfield's Keble College (18681882).

49. Pugin, True Principles, 60. 